\title{
Development of SEA-MEA (Self Efficacy Academic-Means Ends Analysis) Learning Model to Increase Problem Solving Skills
}

\author{
Djoni Setiawan \\ LPMP Jawa Timur \\ Surabaya, Indonesia \\ djoni.setiawan@kemdikbud.go.id
}

\author{
Wasis \\ Physics Education Study Program \\ Universitas Negeri Surabaya \\ Surabaya, Indonesia \\ wasis@unesa.ac.id
}

\author{
Budi Jatmiko \\ Physics Education Study Program \\ Universitas Negeri Surabaya \\ Surabaya, Indonesia \\ budijatmiko@unesa.ac.id
}

\begin{abstract}
Problem solving skills are urgently needed in everyday life and teachers should train in this global era. One of the models that can train problem solving skills is problem based learning (PBL) model. PBL model still has some weaknesses. Students find difficulties in the learning, the result of learning concept is still low and students difficult to develop problem solving skills without the guidance and direction of teacher. The results obtained during the learning process are problem solving skills still low (57\%) and learning process using the PBL model found some weaknesses, namely: teachers guiding students to find real problems $(26 \%)$ and trained problem solving skills $(30 \%)$. Therefore it is necessary to develop a learning model that can effectively train problem solving skills during the learning process and the end of result. The learning model developed is SEA-MEA model. The theory of self efficacy academic (SEA) and means ends analysis (MEA) underlies the development of the SEA-MEA model. The MEA strategy can make it easier for students to solve problems and self efficacy can motivate and find real problems in learning. This innovative learning model is expected can train problem solving skills in a practical, valid and effective.
\end{abstract}

Keywords-model SEA-MEA, problem solving, means ends analysis, self efficacy academic

\section{INTRODUCTION}

Problem solving skills are important. Problem solving is a key of The purpose of solving that intact and complex is broken down into some simpler goals. enter REAL life activities [1] The purpose of solving that intact and complex is broken down into some simpler goals The purpose of solving that intact and complex is broken down into some simpler goals. complex is broken down into some simpler goals. On the job. In everyday life, these skills are more widely used than interpersonal skills, management, and writing skills $[3,4,5]$. According to P21st Century Student Outcomes, problem solving skills should be a 21 st century learning outcome.

Problem solving skills help students be easier to learn concepts. Problem solving skills develop based on active intellectual engagement, not only involving passive observation and algorithms application, but also requiring students' thinking [6]. Problem solving skills can help students to find systemati and logical information by considering different perspectives of solutions. Conversely, the lack of problem solving skills causes students to have unfavorable habits which are doing various activities without knowing the purpose and reason.

Problem solving strategies which were used in the development of this learning model was the heuristic means-ends analysis (MEA) [7, 9, 10, 11]. MEA is one of the problem-solving strategies [11]. MEA is a strategy which sets the intact goals into sub-goals. The purpose of solving is to break down intact and complex goals into simple goals. Meanwhile, the problems which include in PBL learning model [12], are still intact completed by students. Research of [13] shows that problem solving skills are increasing using the MEA strategy. The MEA strategy makes problem solving be easier and better. That is the reason why MEA was chosen as prolem solving strategy.

Based on the problems found in the preliminary study, a theoretical study of the PBL, CPS models, and previous studies, an innovative learning model should be developed. Learning model can improve students' problem solving skills. Problem solving skills which is using MEA heuristic strategy can enhance students' self efficacy in science learning.

\section{METHOD}

The method used in this research is qualitative method. The design of this Research Study Reuters was R and D. Stages of this research were 1) preliminary study, 2) design of model prototype.

\section{RESULT AND DISCUSSION}

\section{a) Problem Solving Skill}

The problem is defined as a situation where there is a separation between the real conditions and the desired conditions. The problem has an initial condition and a path to achieve goal. The problem as a task which has completion procedure is not yet known, so we should find procedures to solve the problem [14]. Dewey explains that the problem occurs when an individual is faced with difficulty answer which is not available [15].

The Factors which affect problem solving are knowledge structure and character of problem which is represented by format of questions [16]. The differences between students who have low ability (novice) and high ability (expert) to solve problems are how students use 
knowledge and connect one concept with another concept $[17,18]$. The structure of knowledge which is possessed by students is called individual constructivist. Individual constructivists are inspired by Piaget. Individual constructivist focus on how individuals build knowledge in their minds. Characteristics of constructivism learning methods is connecting students' experience to develop meaningful understanding.

Means Ends Analysis (MEA) as a problem solving strategy that compares beetween current state and goals [19]. Furthermore, the differences are divided into several sub problems. After each sub ploblems is solved then overall problems can be solved by using appropriate problem solving. Problems which are set to become sub problems is good choice in learning [20]. It makes student be easier to solve problems in learning. Making the goal to solve problems becomes a sub problems can reduce cognitive loads [20]. Therefore, Means End Analysis is a problem solving strategy used in this development model. Complex problems in learning Science (IPA) are broken down into several sub problems. These simple problems are solved one by one, so students be easier to solve it.

\section{b) Hypothetical Model Development}

Development of hypothetical model is based on preliminary study. The main problem in the preliminary study is to guide students to authentic problems. Teachers are still lacking in authentic problem oriented. Another problem is during the process of problem solving, the teacher has not given assistance to the students in solving the problem. Students' problem solving skills have not been trained in learning process.

Based on theoretical and empirical studies explain that problem based learning model (PBL) has several advantages and disadvantages. Some weaknesses of PBL can be eliminited by Cooperative Problem Solving (CPS) learning model. The weakness of this research's hope can be closed by hypothetical model that will be developed. The advantages which are found in the PBL and CPS models are still used in hypothetical models. The development of the SEA-MEA model is also based on problem solving indicators which have not been trained by PBL and CPS models.

The syntax of PBL and CPS show a common pattern that consists of: 1) preparing students to learn by basis problems , 2) solving problems and presenting the results, and 3) reflecting on the process and outcome of the problem so next process of problem solving is better. The weakness of the PBL and CPS model are that students difficulty to formulate the problems as basis of learning [21]. In the hypothetical model, at the beginning of learning, students' activities are directed to formulate an authentic problem. It gave students' ability to relate the learning material. The understanding of their ability is self efficacy as attempting to formulate problems.

Comparison of PBL, CPS, and developed hypothetical models are shown based on outcomes, syntax and weaknesses. The weaknesses which are found can be eliminated by developing hypothetical model. The following are some of the outcomes of the problem based learning model and the developed learning model. Problem based learning models include; PBL[12] and CPS[4]. Comparison of the syntax of each model which became reference for developing model as steps of learning.

Description of outcome and syntax of learning models have several advantages and disadvantages. Further more, in this study the disadvanteges can reduced by the developed hyothetical model. The summary of outcome and syntax of PBL, CPS, and hypothetical model are shown on Table 1

TABLE 1 COMPARISON PBL, CPS AND HYPHOTHETIC MODEL (SEA-MEA)

\begin{tabular}{|c|c|c|c|}
\hline $\begin{array}{l}\text { Component of } \\
\text { Model }\end{array}$ & PBL & CPS & Hyphothetic model (SEA-MEA ) \\
\hline Purpose of model & $\begin{array}{l}\text { Increase the critical thinking.and problem } \\
\text { solving skills } \\
\text { Have good behavior and social skills } \\
\text { Make students become independent learners } \\
(P B L) \\
\qquad[12] \\
\qquad \text { Disadvantages: } \\
\text { Less knowledge acquisition [22],_[23]. } \\
\text { The PBL model is suitable for students with } \\
\text { good-structured knowledge [24]. } \\
\text { Raise students' stress and PBL is costly } \\
\text { developing } \\
\text { The result of problem solving skills is low } \\
(57 \%) \text {. }\end{array}$ & $\begin{array}{l}\text { Increase the problem solving skills } \\
\text { Improving work skills in groups } \\
\text { Students have motivation } \\
\text { (Cooperative Problem Solving in } \\
\text { Physics) } \\
\qquad \text { Advantages of CPS } \\
\text { Achieving understanding of concepts } \\
\text { by CPS model is better than } \\
\text { individual learning [25] } \\
\text { Complete problem solving can be } \\
\text { easier done on groups[26] } \\
\qquad \text { Disadvantages } \\
\text { Students' anxiety has not been } \\
\text { resolved }\end{array}$ & $\begin{array}{l}\text { Increase the problem solving skills } \\
\text { Increase conceptual understanding } \\
\text { Eliminate the advantages: } \\
\text { Increase understanding of concepts } \\
\text { both individual and group learning } \\
\text { Reduce cognitive burden by making } \\
\text { the goal of problem solving into a } \\
\text { sub goal [20][27] } \\
\text { Self efficacy can overcome stressful } \\
\text { in solving problems [28] }\end{array}$ \\
\hline Syntax of model & $\begin{array}{l}\text { On initial learning, students formulate the } \\
\text { problem as a basis in the learning model } \\
\text { (students are oriented to the problem) } \\
\text { Obstacles } \\
1 . \quad \text { The students are difficult to } \\
\text { formulate the problem. } \\
2 \text {. In syntax of group investigation, } \\
\text { strategy of problem solving has not been } \\
\text { given clearly }\end{array}$ & $\begin{array}{l}\text { The CPS syntax which begun with } \\
\text { planning and resolving the problem }\end{array}$ & $\begin{array}{l}\text { Early in student learning is required } \\
\text { to remember their capabilities[29]. } \\
\text { This step is an attempt to show } \\
\text { students what has been mastered } \\
\text { and directed to be able to formulate } \\
\text { the problem. } \\
\text { Step which is using to resolve } \\
\text { issues is Means and analysis (MEA) }\end{array}$ \\
\hline
\end{tabular}


The major indicators of problem solving are covered in PBL and CPS syntax, but some indicators have not been trained on both models. Therefore, syntax of hypothetical model (SEA-MEA) is prepared with reference of several theoretical studies. The problem solving indicators which were trained on each syntax of PBL model, CPS and hypothetical models are described on below:

\section{1) Representation}

The reactualization phase which trains students to recall information that has ever been mastered. Recalling information relating performance is the dominant source of self efficacy [30,31]. Great self efficacy can support them to continue next phase with more leverage [32]. The information which is being mastered and recalled is relevant to learning material. Based on past accomplishments of performanece and next task challenges (problems to be solved), students can practice to set realistic goals.

\section{2) Planning}

The reactualization phase which trains students to recall performance of problem solving is similar to the problems faced in this lesson. Encountered problems can be similar problems but has greater challenges. Problems with greater challenges will be readily resolved if the goal of problem solving is divided into sub goals. Students' cognitive load are lighter by breaking the goal into sub goal of problem solving. Its setting which was used on Means Ends Analysis (MEA) by Newell, Shaw and Simon in 1950 .

\section{3) Execution}

The syntax of the embedded model describe the problem can organize student in the learning. Indicators planned as an approach to checks the problem required and set appropriate time for learning. The indicators recall problem which is relevant and similar with previous tasks and identify sub goals. The embodied syntax of the hypothetical model execute the sub goal and solve problem..

\section{4) Reflection}

The embedded syntax of model was evaluated by CPS and evaluate PBL. The indicator contained efficacy of problem approach and the encountered problem. Indicators that are not enclosed are anticipating situations in which current problem approach might be useful. The embodied syntax of the hypothetical model is reflected on the problem situation and the thinking process used to academic self efficacy.

\section{CONCLUSION}

SEA-MEA model is designed based on indicators of the problem solving skills. SEA-MEA learning model are expected to develop problem solving skills and self efficacy. Suggestions for further Research, the development of SEA-MEA learning model is still theoretical, so It needs to be tested and implemented in the classroom.

\section{REFERENCES}

[1] S. Krulik and J. A. Rudnick, The New Sourcebook for Teaching Reasoning and Problem Solving in Junior and Senior High School, Boston: Allyn \& Bacon, 1996.

[2] P. Peng, Successful Problem-Based Learning for Primary and Secondary Classrooms Singapore: Federal Publication, 2004.

[3] NSTA Position Statement: Elementary School Science, National Science Teachers Association, 2002,. [Online]. Available:

http://www.nsta.org/about/positions/elementary.aspx].\%0A Onwuegbuze, A. J., \& Leech, N. L. (2005). Taking the "Q" ou.

[4] K. Heller and P. Heller, Cooperative Problem Solving in Physics, A User 's Manual Minnesota, 2010.

[5] I. Belski, J. Baglin and J. Harlim, "Teaching TRIZ at University: A Longitudinal Study, “ Int. J. Eng. Educ., pp. 346-354, 2013.

[6] R. Foshay and J. Kirkley, Principles for Teaching Problem Solving, pp. 1-16, 2003.

[7] A. Woolfolk-Hoy, W. K. Hoy and H. A. Davis, Teachers'self-efficacy Beliefs, Handb. Motiv. Sch, pp. 627654, 2009.

[8] D. P. Maloney, "An Overview of Physics Education Research on Problem Solving,” Res. Probl. Solv., pp. 1-33, 2011.

[9] L. Simon, Visualization for Hyper-Heuristics: Back-End Processing SAND2015-2327R, 2011.

[10] L. Kroenung, Visualization for Hyper-Heuristics : Front-End Graphical User Interface SAND2015-2324R Vis, 2015.

[11] R. E. Korf, Real-time Heuristic Search, Artif. Intellegence, vol 42, pp. 189-211, 1990.

[12] R. Arends and A. Kilcher, Learning for Student Learning, Becoming an Accomplished Teacher Ninth Edit New York: Mc Graw-Hill, 2012.

[13] M. L. Gick, "Problem-solving Strategies," Educ. Psy., pp. 37-41, 2012.

[14] L. W. Anderson and D. R. Krathwohl, A Taxonommy for Learning, Teaching, and Assesing: A Revision of Bloom's Taxonomy of Educational Objectives. New York: Addison Wesley Longman, Inc, 2001.

[15] R. Moreno, Educational Psychology, John Wiley and Sons, 2010.

[16] M. De Cock, Representation Use and Strategy Choice in Physics Problem Solving," Phys. Rev. ST Phys. Educ. Res., vol 8, pp. 20117, 2012.

[17] A. Mason and C. Singh, "Assessing Expertise in Introductory Physics Using Categorization Task," vol 20110, p. 1-17, March 2011

[18] S. Lin and C. Singh, "Using Isomorphic Problems to Learn Introductory Physics," Phys. Educ. Res., vol 20104, p. 1-16., March 2011

[19] D. Mcdermott, A Heuristic Estimator for Means-Ends Analysis in Planning, 1996. 
[20] S. Lin, Problem Solving, Scaffolding and Learning, National Taiwan University, 2006, unpublished doctoral dissertation.

[21] S. Djoni, Profil Pembelajaran Berbasis Masalah di SMP Jawa Timur Mata Pelajaran IPA in Prosiding Seminar Nasional Tahun 2016 "Mengubah Karya Akademik Menjadi Karya Bernilai Ekonomi Tinggi”, pp. 560-565, 2016.

[22] D. Gijbels, F. Dochy, P. Van den Bossche and M. Segers, Effects of Problem-based Learning: A Meta-Analysis from The Angle of Assessment, pp. 42, 2005.

[23] M. Albanese and S. Mitchell, "Problem Based Learning: A Review of Literature on Its Outcomes and Implementation Issues," Acad. Med., vol. 68, pp.52-81, 1993.

[24] M. Segers, F. Dochy and E. De Corte, Assessment Practices and Students' Knowledge Profiles in a Problem-based Curriculum," Learn. Environ. Res, vol. 2, pp. 191-213, 1999.

[25] K. Jeon and T. Noh, "Instructional Effect of Cooperative Learning in Problem-Solving Strategy SNU," J. Educ. Res., vol.13, pp. 1-26, 2004
[26] P. Heller and K. Heller, Cooperative Group Problem Solving in Discussion Sections, in Cooperative Group Problem Solving in Physics, pp. 37-52, 1999.

[27] L. A. Paul, Why Goal-free Problems can Facilitate Learning, Contemporary Educ. Phsycho., pp. 6, 1993.

[28] A. Erozkan, The Effect of Communication Skills and Interpersonal Problem Solving Skills on Social SelfEfficacy, vol 13, pp. 739-745, 2013.

[29] A. Bandura, "On the functional properties of perceived selfefficacy Revisited," J. Manage. vol. 38, pp. 9-44, 2012,

[30] A. Bandura, Self-Efficacy, Encyclopedia of Human Behavior, vol. 4, pp. 1-14, 1994.

[31] G. Bayramoğlu, "Self-Efficacy in The Workplace: Implications for Motivation and Performance," Int. J. Manag. Bus. Adm., vol. 14, 2011.

[32] L. I. Massa and R. E. Mayer, The Role of Prior Experience in Self-Efficacy Calibration, University of California Santa Barbara, 2005, unpublished doctoral dissertation. 